ISSN 1392-3196 / e-ISSN 2335-8947

Zemdirbyste-Agriculture, vol. 106, No. 2 (2019), p. 135-142

DOI 10.13080/z-a.2019.106.018

\title{
The efficacy of environmentally acceptable products for the control of major potato pests and diseases
}

\author{
Tanja BOHINC, Filip VUČAJNK, Stanislav TRDAN \\ University of Ljubljana \\ Jamnikarjeva 101, 1000 Ljubljana, Slovenia \\ E-mail: tanja.bohinc@bf.uni-lj.si
}

\begin{abstract}
From 2015-2016, different environmentally acceptable products for the control of harmful organisms, including the Colorado potato beetle (Leptinotarsa decemlineata), wireworms (Agriotes spp.), early blight (Alternaria solani) and late blight (Phytophthora infestans), were tested on potatoes. To control the Colorado potato beetle, was tested the efficacy of limestone dust at two concentrations, 345 and $690 \mathrm{~kg} \mathrm{ha}^{-1}$. Brassica pellets $\left(200 \mathrm{~g} \mathrm{~m}^{-2}\right)$ and calcium cyanamide $\left(1000 \mathrm{~kg} \mathrm{ha}^{-1}\right)$ were tested against wireworms. Tincture of propolis and propolis glycolic extract (mentioned as propolis) at 5 and $10 \mathrm{ml}^{-1} \mathrm{H}_{2} \mathrm{O}$ was tested against early and late blight. All of these products were combined into four treatments. Treatment 1 included treatments with limestone dust $\left(690 \mathrm{~kg} \mathrm{ha}^{-1}\right)$, Brassica pellets and propolis $\left(10 \mathrm{ml} \mathrm{l}^{-1} \mathrm{H}_{2} \mathrm{O}\right)$. Treatment 2 included treatments with limestone dust $\left(345 \mathrm{~kg} \mathrm{ha}^{-1}\right)$, calcium cyanamide $\left(1000 \mathrm{~kg} \mathrm{ha}^{-1}\right)$ and propolis $\left(5 \mathrm{ml} \mathrm{l}^{-1} \mathrm{H}_{2} \mathrm{O}\right)$. Treatment 3 was positive control - use of registered phytopharmaceutical plant protection method, and treatment 4 was negative control (untreated plots). The inspection of all developmental stages: egg clusters, first and second instar larvae after hatching (L1-L2), and third and fourth instar larvae after hatching (L3-L4, adults), of the Colorado potato beetle was performed. After harvest, the tuber yield was evaluated. The evaluation of the yield was conducted on the small, medium and large tubers. The amount of damage caused by wireworms on the potato tubers was also detected in the different tubers. Calcium cyanamide was more effective than Brassica pellets against wireworms, whereas at a dose of $10 \mathrm{ml}^{-1} \mathrm{H}_{2} \mathrm{O}$, propolis was proven to be a good alternative for the management of early and late blight under unfavourable weather conditions for an epidemic outbreak. In 2016, the potato tuber yield in all three treatments was significantly higher than that in the untreated plots.

With the combination of the tested products, promising alternative control strategies for future potato production systems might be obtained, which will be suitable for farming under changing climate conditions with a very narrow spectrum of registered phytopharmaceutical plant protection products.
\end{abstract}

Keywords: Brassica pellets, calcium cyanamide, diseases, limestone dust, pests, potato, propolis, yield.

\section{Introduction}

Europe is one of the top regions for food production in the world. Among the cultivated plants in Europe, potato production is fourth, because it is possible in areas with different climates and in different production systems (Pulatov et al., 2016). In Europe, several harmful organisms, including the Colorado potato beetle (Leptinotarsa decemlineata Say), wireworms (Agriotes spp.), late blight (Phytophthora infestans (Mont.) de Bary) and early blight (Alternaria solani (Ellis \& G. Martin) L. R. Jones \& Grout), can cause yield reductions (Kapsa, 2008).

The economically important fungal potato diseases in Europe are late blight and early blight. Frequently excessive and otherwise inappropriate fungicide applications in different potato growing areas are one of the reasons for the fungal resistance of P.infestans (Nærstad et al., 2007), whereas increasingly warm and dry summers and new (environmentally more acceptable) production technologies have significantly increased $A$. solani potato infections (Runno-Paurson et al., 2014; Olle et al., 2015). A high level of potato infection caused by $A$. solani can result in a $20-30 \%$ lower yield (Christ, Haynes, 2001).
Due to its pronounced resistance to insecticides (Alyokhin et al., 2008; Rinkevich et al., 2012; Scott et al., 2014) and climate change, the Colorado potato beetle (CPB) is still one of the most important potato pests, although it has been almost 100 years since its first occurrence in Europe (Wang et al., 2017). Furthermore, wireworms are also important potato pests in Europe. The suppression of wireworms in arable land is usually influenced by a limited number of insecticides, while knowledge of alternative methods for their suppression is usually insufficient (Ritter, Richter, 2013; Sufyan et al., 2013; Rogge et al., 2017). Several alternative plant protection methods can be used for the suppression of organisms that are harmful to potatoes. Wood ash has been shown to be efficient against CPB (Boiteau et al., 2012), since it serves as a physical barrier. In our case, we used limestone dust as a physical barrier. In the search for natural fungicides to be used in potato production, we tested propolis. The antifungal efficacy of propolis has already been reported by Anjum et al. (2018) but has never been tested in field conditions. The application

Please use the following format when citing the article:

Bohinc T., Vučajnk F., Trdan S. 2019. The efficacy of environmentally acceptable products for the control of major potato pests and diseases. Zemdirbyste-Agriculture, 106 (2): 135-142. DOI 10.13080/z-a.2019.106.018 
of Brassica pellets and calcium cyanamide has been previously described by Bohinc and Trdan (2014) as a good alternative method against wireworms.

The purpose of our research was to study the effects of different alternative plant protection products for the suppression of four species of organisms that are harmful to potatoes and to introduce the most efficient product into future environmentally friendly potato production systems.

\section{Materials and methods}

Plant material. The two-year (2015-2016) field experiment was conducted at the Experimental Field $\left(46^{\circ} 04^{\prime} \mathrm{N}, 14^{\circ} 31^{\prime} \mathrm{E}, 299 \mathrm{~m}\right)$ of the Biotechnical Faculty of the University of Ljubljana, Slovenia. In the first year of the study, the experimental field covered $522 \mathrm{~m}^{2}$, whereas in the second year, the area covered $421.2 \mathrm{~m}^{2}$. In the first year, the experiment included the cultivar 'Labadia' (producer: KWS, Germany; supplier: Semenarna Ljubljana Ltd., Slovenia), whereas in the second year, the experiment included the cultivar 'Bonnata' (producer: Stet Holland, Holland; supplier: Semenarna Ljubljana Ltd., Slovenia). 'Labadia' is a traditional early-bulking potato cultivar that is suitable for the fresh market. This cultivar is suitable for all soil types but is susceptible to common scab. 'Labadia' is moderately susceptible to late blight in its foliage and tubers, and conventional treatments are recommended. 'Bonnata' is a mediumearly cultivar that is not resistant to potato cyst nematodes but is resistant to the wart disease fysio 1 . It is rather resistant to common scab and late blight in its foliage. We planted the 'Labadia' on 16 April 2015, and the 'Bonnata' was planted on 4 April 2016.

Crop and soil management practices. The presowing soil preparation in both years involved two passes with a rotary harrow to a depth of $20 \mathrm{~cm}$ in the spring. Between the first and second passes, manure with a nitrogen, phosphorus and potassium (NPK) ratio of 7-2030 at $500 \mathrm{~kg} \mathrm{ha}^{-1}$ was added to the soil. The tuber sowing was conducted with a two-row potato planter (Tehnos Ltd., Slovenia) at a speed of $3 \mathrm{~km} \mathrm{~h}^{-1}$. The weeds were controlled twice (20 April 2015 and 7 April 2016) with the herbicide Plateen WG 41.5 (a.i. metribuzin, 17.5\%) at a dose of $2.5 \mathrm{~kg} \mathrm{ha}^{-1}$ with $300 \mathrm{l}$ of water per hectare. At the beginning of June 2015, we mechanically hoed the earth, whereas on 18 May 2016, we treated the field with the herbicides Sencor SC 600 (a.i. metribuzin) at a dose of $0.15 \mathrm{l} \mathrm{ha}^{-1}$ and Fusilade Forte (a.i. fluazifop-p-butyl $15 \%$ ) at a dose of $0.81 \mathrm{ha}^{-1}$. In both years, the previous crop was winter wheat. In the experimental years, the potato seeding fields were chosen in different locations at the Experimental Field.

Treatments. The experimental area in both experimental years was divided into three blocks. In each block, we randomly allocated 4 plots (treatments). In each treatment, the occurrence of four harmful organisms was investigated. All the treatments along with the application dates and doses are presented in Tables 1 and 2 .

Table 1. The products in the four treatments that were tested against the four organisms that are harmful to potatoes with their application dates in 2015

\begin{tabular}{|c|c|c|c|c|}
\hline Pest / disease & Treatment 1 & Treatment 2 & $\begin{array}{c}\text { Treatment } 3 \\
\text { (positive control) }\end{array}$ & $\begin{array}{c}\text { Treatment } 4 \\
\text { (negative control, } \\
\text { untreated plots) }\end{array}$ \\
\hline $\begin{array}{l}\text { Colorado potato beetle } \\
\text { (Leptinotarsa } \\
\text { decemlineata) }\end{array}$ & $\begin{array}{l}\text { Limestone dust-high } \\
\text { dose }\left(690 \mathrm{~kg} \mathrm{ha}^{-1}\right) \\
\text { applied on } \\
2,22 \text { and } 30 \text { June }\end{array}$ & $\begin{array}{l}\text { Limestone dust-low } \\
\text { dose }\left(345 \mathrm{~kg} \mathrm{ha}^{-1}\right) \\
\text { applied on } \\
2,22 \text { and } 30 \text { June }\end{array}$ & $\begin{array}{l}\text { Actara } 25 \text { WG } \\
\text { (a.i. thiamethoxam, 25\%); } \\
\text { applied on } \\
10 \text { and } 31 \text { July }\end{array}$ & \\
\hline $\begin{array}{l}\text { Wireworms } \\
\text { (Agriotes spp.) }\end{array}$ & $\begin{array}{l}\text { Brassica pellets } \\
\left(200 \mathrm{~g} \mathrm{~m}^{-2}\right) ; \\
\text { applied on } 2 \text { June }\end{array}$ & $\begin{array}{l}\text { Calcium cyanamide } \\
\left(1000 \mathrm{~kg} \mathrm{ha}^{-1}\right) ; \\
\text { applied on } 2 \text { June }\end{array}$ & $\begin{array}{l}\text { Force } 1.5 \mathrm{G} \\
\text { (a.i. tefluthrin, } 1.5 \% \text { ); } \\
\text { applied on } 2 \text { June }\end{array}$ & \\
\hline $\begin{array}{l}\text { Early blight } \\
\text { (Alternaria solani) }\end{array}$ & $\begin{array}{l}\text { Propolis-high dose } \\
\left(10 \mathrm{ml} 1^{-1} \mathrm{H}_{2} \mathrm{O}\right) \\
\text { applied on } \\
2,22 \text { and } 30 \text { June } \\
\text { and } 10,17 \text { and } 31 \text { July }\end{array}$ & $\begin{array}{l}\text { Propolis-low dose } \\
\left(5 \mathrm{ml} 1^{-1} \mathrm{H}_{2} \mathrm{O}\right) \\
\text { applied on } \\
2,22 \text { and } 30 \text { June } \\
\text { and } 10,17 \text { and } 31 \text { July }\end{array}$ & $\begin{array}{l}\text { Ortiva (a.i. azoxystrobin, 50\%) + } \\
\text { Shirlan 500 SC (a.i. fluazinam); } \\
\text { applied on } \\
30 \text { June and } 10 \text { July }\end{array}$ & \\
\hline $\begin{array}{l}\text { Late blight } \\
\text { (Phytophthora infestans) }\end{array}$ & $\begin{array}{l}\text { Propolis-high dose } \\
\left(10 \mathrm{ml} 1^{-1} \mathrm{H}_{2} \mathrm{O}\right) \\
\text { applied on } \\
2,22 \text { and } 30 \text { June } \\
\text { and } 10,17 \text { and } 31 \text { July }\end{array}$ & $\begin{array}{l}\text { Propolis-low dose } \\
\left(5 \mathrm{ml} 1^{-1} \mathrm{H}_{2} \mathrm{O}\right) \\
\text { applied on } \\
2,22 \text {, and } 30 \text { June } \\
\text { and } 10,17 \text { and } 31 \text { July }\end{array}$ & $\begin{array}{l}\text { Polyram DF (a.i. metiram, 70\%); } \\
\text { applied on } 2 \text { and } 22 \text { June and } 21 \text { July. } \\
\text { Shirlan } 500 \text { SC (a.i. fluazinam) }+ \\
\text { Ortiva (a.i. azoxystrobin); } \\
\text { applied on } 30 \text { June and } 10 \text { July } 2015\end{array}$ & \\
\hline
\end{tabular}

In 2015, a tincture of propolis that was prepared by the beekeeping family Plut from Krvavčji Vrh in the municipality of Semič, Slovenia was applied. In the second year (2016) of the study, a propolis glycolic extract - liquid: water and propylene glycol (B NATURAL, Italy) was used. This preparation contained 20\% natural propolis and is also marketed by the manufacturer as a fungicide. According to the producer, the following components have been detected in the product: $0.50 \mathrm{mg}$ $\mathrm{ml}^{-1}$ of quercetin, $1.52 \mathrm{mg} \mathrm{ml}^{-1}$ of apigenin, $0.69 \mathrm{mg} \mathrm{ml}^{-1}$ of pinobanksin, $17.00 \mathrm{mg} \mathrm{ml}^{-1}$ of chrysin, $1.30 \mathrm{mg} \mathrm{ml}^{-1}$ of pinocembrin and $11.94 \mathrm{mg} \mathrm{ml}^{-1}$ of galangin.

Limestone dust was obtained from the local manufacturer (Apnenec Ltd., Slovenia). The dust contained 97.70\% $\mathrm{CaCO}_{3}$. Lime nitrogen (Bird d.o.o.,

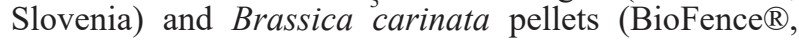
Italy) were applied to the soil during the earthing up in both years of the experiment, namely, on 2 June 2015 and 4 June 2016 . The lime nitrogen consisted of $19.80 \%$ total nitrogen, $1.5 \%$ nitrate nitrogen, $>15 \%$ cyanamide nitrogen, approx. $0.5 \%$ dicyanamide nitrogen, $>50 \%$ calcium oxide $(\mathrm{CaO}), 12 \%$ carbon $(\mathrm{C}), 10 \%$ calcium carbonate $\left(\mathrm{CaCO}_{3}\right), 2 \%$ calcium sulphate $\left(\mathrm{CaSO}_{4}\right), 2 \%$ magnesium carbonate $\left(\mathrm{MgCO}_{3}\right)$ and $2 \%$ mineral oxidases and hydroxides. The Brassica pellets contained $6.0 \%$ organic nitrogen, $2.2 \%$ phosphorus, $2.0 \%$ potassium, $45.0 \%$ organic carbon and $4.0 \%$ water.

The potatoes were harvested with an IK-1 $D$ back output machine (Tehnos Ltd., Slovenia) with two rolling plates on 13 August 2015 and 24 August 2016. The potatoes were picked manually. On the day of the harvest, the tubers were sorted with a special shaking device Strzelec M637 (Krukowiak, Poland) into three fractions: small $(<4 \mathrm{~cm})$, medium (between 4 and $5 \mathrm{~cm}$ ) and large $(>5 \mathrm{~cm})$. 
Table 2. The products in the four treatments that were tested against the four organisms that are harmful to potatoes with application dates in 2016

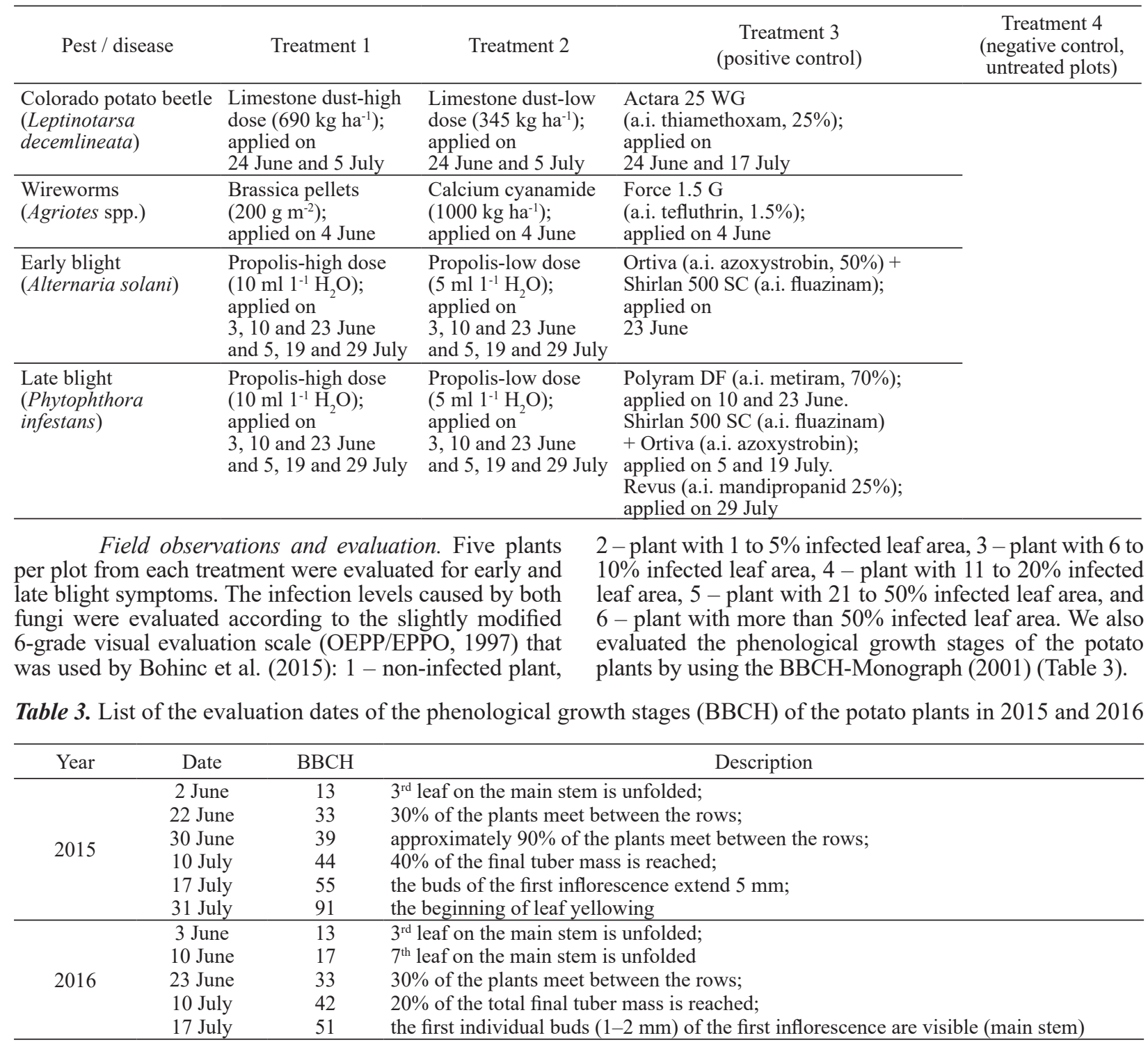

In 2015, the evaluations of the infected leaf area (with early blight only) were performed four times: on 10, 17 and 31 July and 7 August. In 2016, we assessed the leaf areas infected with early and late blight six times: on 20 and 24 June, 1, 10 and 27 July and 5 August. For the $\mathrm{CPB}$, we counted the egg clusters of young larvae (as L1-L2 larvae), old larvae (as L3-L4 larvae) and adults according to Laznik et al. (2010). The counting of individuals of different developmental stages of CPB was performed on five potato plants from the central area of the specific treatment plots. A visual inspection was made on the five successive selected plants in each treatment, and the different CPB developmental stages were counted throughout the experiment. Throughout the entire growing season, the early and late blight monitoring and the CPB counting was always performed on the same plants, because the number of CPB larvae and adults was not large, and consequently, the potato leaves were not severely injured. The injuries caused by the wireworms were counted on the potato tubers in each specific tuber size fraction per treatment. In 2015, a total of 35 tubers per size fraction were examined per treatment, whereas in 2016, 21 tubers were evaluated per fraction. All of the tubers were chosen randomly. On each tuber, the holes (injuries) were counted according to the method of Laznik et al. (2014).
Weather conditions. The climate data were obtained from the bulletin "Naše okolje", which is published monthly by the Slovenian Environment Agency (2018). An analysis was performed from data period 1981-2010 according to the average values from 1981 to 2010. A value of 0 represented the average temperature from 1981 to 2010. According to the data, 2015 was significantly warmer than the 30 -year average value and more temperate than 2016 (Fig. 1). In 21 of the 30 total ten-day periods in the two years of the experiment, the average temperature from 1981-2010 was exceeded; in most cases (16 ten-day periods), the temperature was more than $2{ }^{\circ} \mathrm{C}$ above the average value for the period.

When both years of the experiment were compared with the 30-year average precipitation, we concluded that both experimental years were drier than the period from 1981-2010 (Fig. 2). In 21 of the 30 total ten-day periods in the two years of the experiment, we recorded less precipitation than that recorded from 1981-2010; in 11 of the ten-day periods, the precipitation was at least $50 \%$ lower than the 30 -year average. Four precipitation peaks were conspicuous, namely, the $3^{\text {rd }}$ ten-day period in June and July 2015 and the $2^{\text {nd }}$ ten-day period in May and June 2016, when 140 (the $2^{\text {nd }}$ ten-day period in June 2016 ) to $260 \%$ (the $2^{\text {nd }}$ ten-day period 


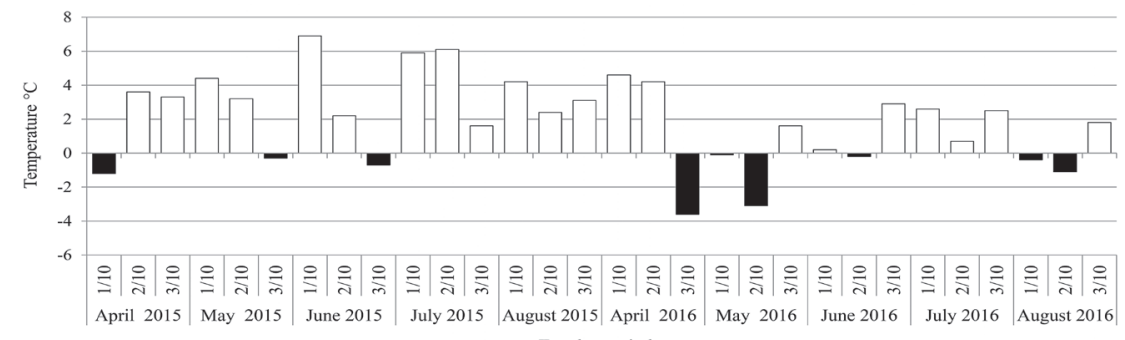

Ten-day period

Note. $1 / 10$ indicates the $1^{\text {st }}$ ten-day increment, $2 / 10$ - the $2^{\text {nd }}$ ten-day increment and $3 / 10$ - the $3^{\text {rd }}$ ten-day increment.

Figure 1. Deviations of the ten-day period temperatures from the average temperatures from 1981 to 2010

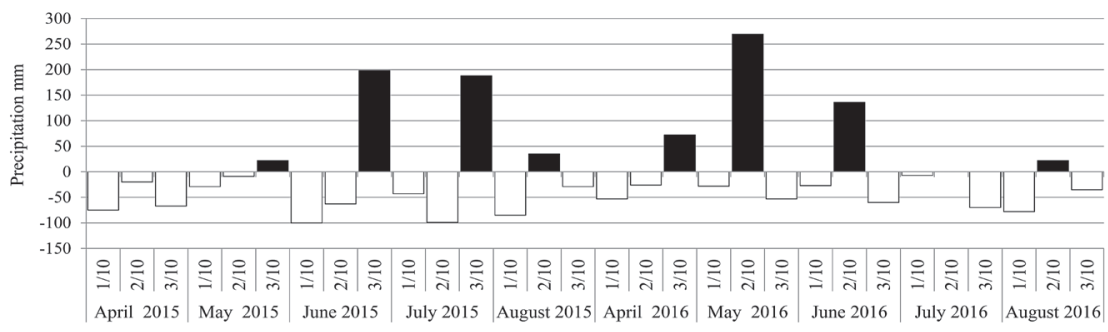

Ten-day period

Note. $1 / 10$ indicates the $1^{\text {st }}$ ten-day increment, $2 / 10$ - the $2^{\text {nd }}$ ten-day increment and $3 / 10$ - the $3^{\text {rd }}$ ten-day increment.

Figure 2. Deviations of the ten-day precipitation periods from the average precipitation from 1981 to 2010

in May 2016) more precipitation than the average for the 30-year period was recorded in Ljubljana, Slovenia.

Statistical analysis. Analysis of variance (ANOVA) was conducted to establish the differences among the treatments within the evaluation parameters. Differences in the numbers of CPB in their developmental stages (egg clusters, L1-L2, L3-L4 and adults), infections by early blight and by late blight, and the injuries caused by wireworms among the individual treatments in addition to differences in the yield were analysed with $A N O V A$. Before analysis, each variable was tested for homogeneity of variance, and non-homogenous data were $\log (\mathrm{Y})$ transformed prior to the ANOVA. Significant differences $(P \leq 0.05)$ between the mean values were identified using Tukey's honestly significant difference (HSD) multiple range test. All statistical analyses were performed using software Statgraphics Centurion XVI (Statgraphics Technologies Inc., USA), and the results are presented as the untransformed mean \pm the standard error (SE).

\section{Results}

Management of early blight in 2015. Based on the analysis of the experimental results, the infection caused by early blight was influenced by the treatment $(F=23.15, \mathrm{df}=3, P<0.0001)$ and evaluation date $(F=26.33$, df $=3, P<0.0001)$ and their interaction $(F=7.34, \mathrm{df}=9, P<0.0160)$. When propolis was applied at the high dose (treatment 1), no more than $6 \%$ of the infected leaf area was detected $(2.46 \pm 0.16)$ on 10 July (Fig. 3). On 17 July, the infected leaf area in all treatments did not exceed, on average, $11 \%$ of the infected leaf area. For example, the level of infection detected in treatment 4 (negative control) was $3.13 \pm 0.21$, and the level of infection detected on the plants in treatment 1 was 2.6 \pm 0.19 . On 7 August, the plants in treatment 4 (negative control) had the highest infection rate $(3.73 \pm 0.15)$.

Management of early blight and late blight in 2016. Based on the analysis of the general results, the infection caused by early blight was influenced by the treatment $(F=5.31, \mathrm{df}=3, P=0.0014)$ and evaluation date $(F=234.53$, df $=5, P<0.0001)$. The effect of the interaction between the evaluation date and the treatment was not significant $(F=1.54$, df $=15, P=0.0905)$.

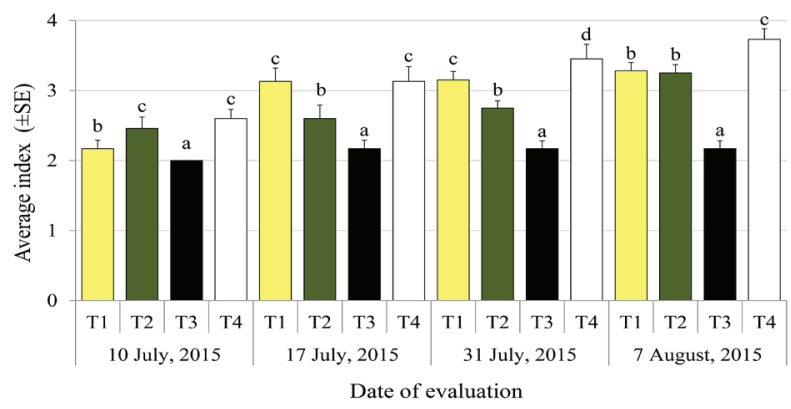

Note. Lowercase letters indicate differences between treatments within a specific date of evaluation); T1 - treatment $1, \mathrm{~T} 2-$ treatment 2, T3 - treatment 3, T4 - treatment 4.

Figure 3. Average index of infection caused by early blight in 2015

On the first evaluation date, the lowest infection rate was detected in treatment $3(1.13 \pm 0.09)$. For treatment 1 , the level of infection caused by early blight reached $1.33 \pm$ 0.12 . On 1 July, the infection rate reached $2.14 \pm 0.23$ on the plants in treatment 2. On 27 July, the level of infection caused by early blight was the highest on the plants in treatment $4(4.37 \pm 0.22)$. On 5 August, the infection by early blight reached $5.00 \pm 0.00$ in treatment 4 , whereas the infection in treatment 4 was $4.05 \pm 0.05$. Based on the analysis of the pooled results, the infection caused by late blight was influenced by the treatment $(F=207.99$, df $=3, P<0.0001)$ and evaluation date $(F=98.67$, $\mathrm{df}=3, P<0.0001)$, and their interaction was significant $(F=13.22, \mathrm{df}=15, P<0.0190)$. When the infection rate was evaluated on 1 July, the infection rate on the plants in treatment 4 was $2.87 \pm 0.12$. Moreover, the same infection rate was detected on 27 July. On 5 August, the highest infection level by late blight was in treatment $4(3.00 \pm$ $0.00)$, whereas the lowest level was detected in the plants in treatment $1(1.73 \pm 0.11)$ (Figs 4 and 5).

Management of $C P B$ from 2015 to 2016. In 2015, the number of CPB adults was influenced by the evaluation date $(F=9.68, \mathrm{df}=5, P<0.0001)$ and the interaction between the exposure date and the treatment $(F=1.82, \mathrm{df}=5, P=0.0303)$. The number of CPB adults 


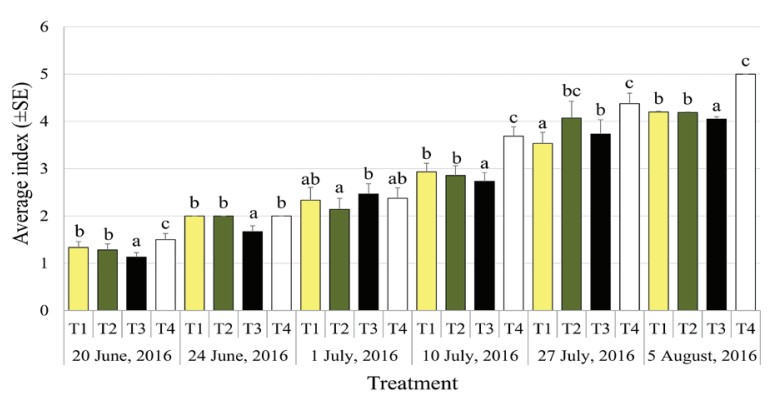

Explanation under Figure 3

Figure 4. Average index of infection caused by early blight in 2016

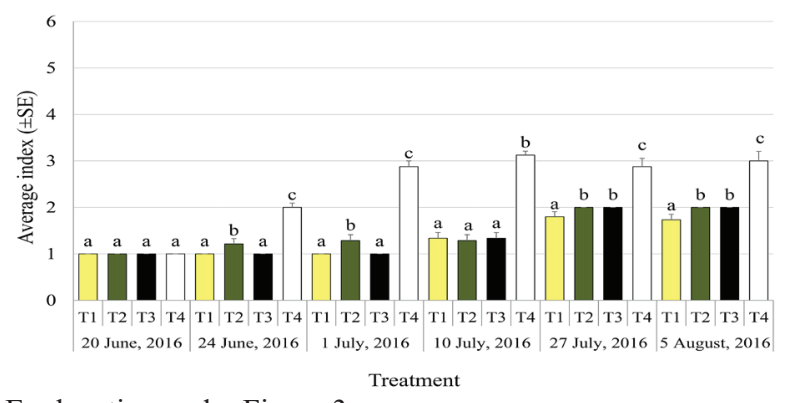

Explanation under Figure 3

Figure 5. Average index of infection caused by late blight in 2016

was not influenced by the treatment $(F=1.61$, df $=3$, $P=0.1859$ ). Similarly, we did not detect a treatment effect on the egg clusters $(F=2.15, \mathrm{df}=3, P=0.1510), \mathrm{L} 1-\mathrm{L} 2$ larvae $(F=1.01, \mathrm{df}=3, P=0.3892)$ or L3-L4 larvae $(F=1.19$, df $=3, P=0.3136)$. We detected an effect of the evaluation date on the egg clusters $(F=2.44, \mathrm{df}=5$, $P=0.0144), \mathrm{L} 1-\mathrm{L} 2$ larvae $(F=2.39, \mathrm{df}=5, P=0.0387)$ and L3-L4 larvae $(F=2.55, \mathrm{df}=5, P=0.2592)$. Additionally, no effect of the interaction between the evaluation date and the treatment was detected on the egg clusters $(F=3.00, \mathrm{df}=15, P=0.0655)$, L1-L2 larvae $(F=1.18, \mathrm{df}=15, P=0.3212)$ or L3-L4 larvae $(F=1.21, \mathrm{df}=15, P=0.2599)$ (Table 4).

In 2016, the number of CPB adults $(F=9.68$, df $=5, P<0.0001)$, egg clusters $(F=25.89, \mathrm{df}=5$, $P<0.0001), \mathrm{L} 1-\mathrm{L} 2$ larvae $(F=2.39, \mathrm{df}=5, P=0.0380)$ and L3-L4 larvae $(F=2.55, \mathrm{df}=5, P=0.0278)$ were influenced by the evaluation date. Based on the results of the general analysis and the pooled results, no treatment effect was detected on the CPB adults $(F=1.61, \mathrm{df}=3$, $P=0.1859)$, egg clusters $(F=0.48, \mathrm{df}=3, P=0.6978)$, L1-L2 larvae $(F=1.01, \mathrm{df}=3, P=0.3892)$ or L3-L4 larvae $(F=1.19, \mathrm{df}=3, P=0.3136)$. We also detected the effect of the interaction between the treatment and the evaluation date on the CPB adults $(F=1.81, \mathrm{df}=15$, $P=0.0303$ ), although no effect of the interaction between the treatment and the evaluation date was detected for the L1-L2 larvae $(F=1.18, \mathrm{df}=15, P=0.2892)$, L3-L4 larvae $(F=1.21, \mathrm{df}=15, P=0.2592)$ or egg clusters $(F=0.55, \mathrm{df}=15, P=0.9134)($ Table 5$)$.

On the first evaluation date, the highest number of L3-L4 larvae were detected on the plants in treatment 3 $\left(3.47 \pm 2.33\right.$ larvae plant $\left.{ }^{-1}\right)$, because no insecticides were used up until that point. The same result was observed for the L1-L2 larvae $\left(2.13 \pm 1.17\right.$ larvae plant $\left.^{-1}\right)$. On 27 July $\left(5.25 \pm 1.71\right.$ larvae plant $\left.^{-1}\right)$ and 5 August $(1.93 \pm 0.94$ larvae plant ${ }^{-1}$ ), the highest number of L3-L4 larvae were on the plants in treatment 4.

Injuries caused by wireworms. In 2015, based on the analysis of the pooled results, the number of injuries (holes) caused by wireworms was influenced by the treatment $(F=1.68, \mathrm{df}=3, P=0.04696)$ but not by the distance between the potato plants and the grassland, which was near the field $(F=2.24, \mathrm{df}=4, P=0.0626)$. In 2016 , based on the analysis of the pooled results, the number of injuries caused by wireworms was influenced by the treatment $(F=1.65, \mathrm{df}=2, P=0.0298)$ but not by the distance between the potato plants and the grassland, which was near the field $(F=3.35, \mathrm{df}=4, P=0.0626)$. In 2015, the injuries caused by wireworms ranged from $0.07 \pm 0.01$ holes per tuber in treatment 2 to $0.04 \pm 0.01$ holes per tuber in treatments 1 and 3. In 2016, the injuries caused by wireworms ranged from $0.56 \pm 0.07$ holes per tuber in treatment 4 to $0.34 \pm 0.07$ holes per tuber in treatment 3 . All the values are presented in Table 6.

Average yield (2015-2016). The data collected in 2015 showed the effect of the treatment on small tubers $(F=2.17, \mathrm{df}=3, P<0.0001)$, medium $(F=3.17, \mathrm{df}=3$, $P=0.0021)$ and large $(F=4.12, \mathrm{df}=3, P<0.0001)$ tubers. The average total yield was also influenced by the treatment $(F=10.18$, df $=3, P<0.0001)$. Based on the results of our survey, we confirmed that the treatment effect of the different formulations was also detected among the small tubers $(F=3.19$, df $=3$, $P=0.0233)$. The average total yield was the lowest in treatment $1\left(32.21 \pm 0.36 \mathrm{tha}^{-1}\right)$, whereas no differences were detected among treatments $2\left(35.19 \pm 0.87 \mathrm{tha}^{-1}\right)$, $3\left(35.36 \pm 0.54 \mathrm{tha}^{-1}\right)$ and $4\left(34.78 \pm 0.95 \mathrm{t} \mathrm{ha}^{-1}\right)$. The

Table 4. The number of Colorado potato beetles in each developmental stage per plant on a specific evaluation date in the various treatments in 2015

\begin{tabular}{|c|c|c|c|c|c|}
\hline & Evaluation date & Treatment 1 & Treatment 2 & Treatment 3 & Treatment 4 \\
\hline \multirow{6}{*}{ Egg clusters } & 22 June & $0.00 \pm 0.00 \mathrm{a}$ & $0.00 \pm 0.00 \mathrm{a}$ & $0.00 \pm 0.00 \mathrm{a}$ & $0.00 \pm 0.00 \mathrm{a}$ \\
\hline & 30 June & $0.00 \pm 0.00 \mathrm{a}$ & $0.00 \pm 0.00 \mathrm{a}$ & $0.13 \pm 0.13 \mathrm{a}$ & $0.60 \pm 0.60 \mathrm{a}$ \\
\hline & 10 July & $0.00 \pm 0.00 \mathrm{a}$ & $0.00 \pm 0.00 \mathrm{a}$ & $0.00 \pm 0.00 \mathrm{a}$ & $0.00 \pm 0.00 \mathrm{a}$ \\
\hline & 17 July & $0.00 \pm 0.00 \mathrm{a}$ & $0.33 \pm 0.19 b$ & $0.40 \pm 0.21 \mathrm{~b}$ & $0.93 \pm 0.28 \mathrm{c}$ \\
\hline & 31 July & $0.46 \pm 0.23 \mathrm{a}$ & $0.40 \pm 0.21 \mathrm{a}$ & $0.20 \pm 0.10 \mathrm{a}$ & $0.46 \pm 0.23 \mathrm{a}$ \\
\hline & 7 August & $1.20 \pm 0.34 \mathrm{bc}$ & $0.93 \pm 0.28 \mathrm{~b}$ & $1.27 \pm 0.23 \mathrm{c}$ & $0.33 \pm 0.15 \mathrm{a}$ \\
\hline \multirow{6}{*}{$\begin{array}{l}\text { L1-L2 } \\
\text { larvae }\end{array}$} & 22 June & $0.00 \pm 0.00 \mathrm{a}$ & $0.00 \pm 0.00 \mathrm{a}$ & $0.33 \pm 0.19 b$ & $0.93 \pm 0.28 \mathrm{c}$ \\
\hline & 30 June & $0.00 \pm 0.00 \mathrm{a}$ & $0.00 \pm 0.00 \mathrm{a}$ & $0.20 \pm 0.14 \mathrm{~b}$ & $2.73 \pm 1.84 \mathrm{c}$ \\
\hline & 10 July & $0.00 \pm 0.00 \mathrm{a}$ & $0.00 \pm 0.00 \mathrm{a}$ & $0.00 \pm 0.00 \mathrm{a}$ & $0.00 \pm 0.00 \mathrm{a}$ \\
\hline & 17 July & $0.00 \pm 0.00 \mathrm{a}$ & $0.00 \pm 0.00 \mathrm{a}$ & $0.00 \pm 0.00 \mathrm{a}$ & $0.00 \pm 0.00 \mathrm{a}$ \\
\hline & 31 July & $0.13 \pm 0.13 \mathrm{a}$ & $0.00 \pm 0.00 \mathrm{a}$ & $0.00 \pm 0.00 \mathrm{a}$ & $0.13 \pm 0.13 \mathrm{a}$ \\
\hline & 7 August & $0.60 \pm 0.03 \mathrm{c}$ & $0.20 \pm 0.10 \mathrm{~b}$ & $0.00 \pm 0.00 \mathrm{a}$ & $2.00 \pm 1.05 \mathrm{~d}$ \\
\hline \multirow{6}{*}{$\begin{array}{l}\text { L3-L4 } \\
\text { larvae }\end{array}$} & 22 June & $0.60 \pm 0.43 \mathrm{~b}$ & $0.60 \pm 0.60 \mathrm{a}$ & $1.93 \pm 1.66 \mathrm{~b}$ & $1.00 \pm 0.52 \mathrm{ab}$ \\
\hline & 30 June & $0.00 \pm 0.00 \mathrm{a}$ & $0.00 \pm 0.00 \mathrm{a}$ & $0.00 \pm 0.00 \mathrm{a}$ & $0.60 \pm 0.60 \mathrm{a}$ \\
\hline & 10 July & $0.60 \pm 0.60 \mathrm{a}$ & $0.00 \pm 0.00 \mathrm{a}$ & $0.00 \pm 0.00 \mathrm{a}$ & $1.40 \pm 0.84 \mathrm{~b}$ \\
\hline & 17 July & $0.00 \pm 0.00 \mathrm{a}$ & $0.00 \pm 0.00 \mathrm{a}$ & $0.00 \pm 0.00 \mathrm{a}$ & $1.40 \pm 0.84 b$ \\
\hline & 31 July & $0.33 \pm 0.33 \mathrm{a}$ & $0.00 \pm 0.00 \mathrm{a}$ & $0.00 \pm 0.00 \mathrm{a}$ & $0.00 \pm 0.00 \mathrm{a}$ \\
\hline & 7 August & $0.00 \pm 0.00 \mathrm{a}$ & $0.93 \pm 0.46 \mathrm{~b}$ & $0.00 \pm 0.00 \mathrm{a}$ & $0.46 \pm 0.23 \mathrm{~b}$ \\
\hline \multirow{6}{*}{ Adults (imago) } & 22 June & $0.00 \pm 0.00 \mathrm{a}$ & $0.00 \pm 0.00 \mathrm{a}$ & $0.00 \pm 0.00 \mathrm{a}$ & $0.00 \pm 0.00 \mathrm{a}$ \\
\hline & 30 June & $0.00 \pm 0.00 \mathrm{a}$ & $0.00 \pm 0.00 \mathrm{a}$ & $0.00 \pm 0.00 \mathrm{a}$ & $0.00 \pm 0.00 \mathrm{a}$ \\
\hline & 10 July & $0.46 \pm 0.46 \mathrm{a}$ & $0.13 \pm 0.13 a$ & $0.06 \pm 0.06 \mathrm{a}$ & $0.26 \pm 0.15 b$ \\
\hline & 17 July & $0.06 \pm 0.06 \mathrm{~b}$ & $0.06 \pm 0.06 \mathrm{~b}$ & $0.00 \pm 0.00 \mathrm{a}$ & $0.00 \pm 0.00 \mathrm{a}$ \\
\hline & 31 July & $0.40 \pm 0.13 \mathrm{c}$ & $0.13 \pm 0.09 \mathrm{~b}$ & $0.00 \pm 0.00 \mathrm{a}$ & $0.26 \pm 0.20 \mathrm{bc}$ \\
\hline & 7 August & $0.20 \pm 0.05 \mathrm{a}$ & $1.06 \pm 0.40 \mathrm{c}$ & $0.33 \pm 0.15 \mathrm{ab}$ & $0.66 \pm 0.20 \mathrm{~b}$ \\
\hline
\end{tabular}

Note. Lowercase letters indicate differences between the treatments within a specific evaluation date. 
Table 5. The number of Colorado potato beetles in each developmental stage per plant on a specific evaluation date in the various treatments in 2016

\begin{tabular}{|c|c|c|c|c|c|}
\hline & Evaluation date & Treatment 1 & Treatment 2 & Treatment 3 & Treatment 4 \\
\hline \multirow{6}{*}{ Egg clusters } & 20 June & $0.66 \pm 0.41 \mathrm{~b}$ & $0.07 \pm 0.07 \mathrm{a}$ & $0.00 \pm 0.00 \mathrm{a}$ & $0.06 \pm 0.06 \mathrm{a}$ \\
\hline & 24 June & $0.20 \pm 0.10 \mathrm{a}$ & $0.14 \pm 0.09 a$ & $0.13 \pm 0.09 \mathrm{a}$ & $0.12 \pm 0.08 \mathrm{a}$ \\
\hline & 1 July & $0.20 \pm 0.10 b$ & $0.14 \pm 0.09 \mathrm{~b}$ & $0.00 \pm 0.00 \mathrm{a}$ & $0.31 \pm 0.21 \mathrm{~b}$ \\
\hline & 10 July & $0.00 \pm 0.00 \mathrm{a}$ & $0.28 \pm 0.16 b$ & $0.00 \pm 0.00 \mathrm{a}$ & $0.00 \pm 0.00 \mathrm{a}$ \\
\hline & 27 July & $0.00 \pm 0.00 \mathrm{a}$ & $0.36 \pm 0.16 b$ & $0.00 \pm 0.00 \mathrm{a}$ & $0.06 \pm 0.06 \mathrm{a}$ \\
\hline & 5 August & $0.00 \pm 0.00 \mathrm{a}$ & $0.36 \pm 0.17 \mathrm{~b}$ & $0.00 \pm 0.00 \mathrm{a}$ & $0.06 \pm 0.06 \mathrm{~b}$ \\
\hline \multirow{6}{*}{$\begin{array}{c}\text { L1-L2 } \\
\text { larvae }\end{array}$} & 20 June & $0.00 \pm 0.00 \mathrm{a}$ & $1.43 \pm 0.77 b$ & $2.13 \pm 1.17 \mathrm{c}$ & $0.00 \pm 0.00 \mathrm{a}$ \\
\hline & 24 June & $0.00 \pm 0.00 \mathrm{a}$ & $5.21 \pm 4.03 \mathrm{c}$ & $0.00 \pm 0.00 \mathrm{a}$ & $2.87 \pm 1.29 \mathrm{~b}$ \\
\hline & 1 July & $0.60 \pm 0.32 \mathrm{~b}$ & $0.21 \pm 0.21 \mathrm{a}$ & $0.20 \pm 0.20 \mathrm{a}$ & $0.50 \pm 0.35 b$ \\
\hline & $10 \mathrm{July}$ & $1.47 \pm 0.47 \mathrm{~b}$ & $2.21 \pm 1.14 \mathrm{~b}$ & $0.00 \pm 0.00 \mathrm{a}$ & $0.87 \pm 0.87 \mathrm{a}$ \\
\hline & 27 July & $1.06 \pm 0.45 b$ & $1.50 \pm 0.51 \mathrm{c}$ & $0.00 \pm 0.00 \mathrm{a}$ & $0.31 \pm 0.31 \mathrm{a}$ \\
\hline & 5 August & $1.06 \pm 0.45 \mathrm{~b}$ & $1.50 \pm 0.51 \mathrm{~b}$ & $0.00 \pm 0.00 \mathrm{a}$ & $0.31 \pm 0.31 \mathrm{a}$ \\
\hline \multirow{6}{*}{$\begin{array}{c}\text { L3-L4 } \\
\text { larvae }\end{array}$} & 20 June & $0.00 \pm 0.00 \mathrm{a}$ & $0.43 \pm 0.43 \mathrm{a}$ & $3.47 \pm 2.33 \mathrm{~b}$ & $0.00 \pm 0.00 \mathrm{a}$ \\
\hline & 24 June & $0.07 \pm 0.07 \mathrm{a}$ & $2.57 \pm 1.71 \mathrm{~b}$ & $0.46 \pm 0.40 \mathrm{~b}$ & $0.31 \pm 0.31 \mathrm{a}$ \\
\hline & 1 July & $0.40 \pm 0.40 \mathrm{a}$ & $0.21 \pm 0.15 b$ & $0.00 \pm 0.00 \mathrm{a}$ & $1.00 \pm 0.41 \mathrm{c}$ \\
\hline & 10 July & $1.20 \pm 0.39 \mathrm{~b}$ & $0.71 \pm 0.37 \mathrm{~b}$ & $0.00 \pm 0.00 \mathrm{a}$ & $5.68 \pm 2.23 \mathrm{c}$ \\
\hline & 27 July & $2.26 \pm 0.70 b$ & $2.00 \pm 1.42 \mathrm{~b}$ & $0.00 \pm 0.00 \mathrm{a}$ & $5.25 \pm 1.71 \mathrm{c}$ \\
\hline & 5 August & $1.73 \pm 0.43 b$ & $2.00 \pm 1.43 \mathrm{~b}$ & $0.00 \pm 0.00 \mathrm{a}$ & $1.93 \pm 0.94 \mathrm{~b}$ \\
\hline \multirow{6}{*}{ Adults (imago) } & 20 June & $0.06 \pm 0.06 \mathrm{a}$ & $0.00 \pm 0.00 \mathrm{a}$ & $0.00 \pm 0.00 \mathrm{a}$ & $0.00 \pm 0.00 \mathrm{a}$ \\
\hline & 24 June & $0.00 \pm 0.00 \mathrm{a}$ & $0.00 \pm 0.00 \mathrm{a}$ & $0.00 \pm 0.00 \mathrm{a}$ & $0.00 \pm 0.00 \mathrm{a}$ \\
\hline & 1 July & $0.00 \pm 0.00 \mathrm{a}$ & $0.00 \pm 0.00 \mathrm{a}$ & $0.40 \pm 0.27 \mathrm{~b}$ & $0.00 \pm 0.00 \mathrm{a}$ \\
\hline & 10 July & $0.33 \pm 0.27 \mathrm{~b}$ & $0.07 \pm 0.07 \mathrm{a}$ & $0.00 \pm 0.00 \mathrm{a}$ & $0.06 \pm 0.06 \mathrm{a}$ \\
\hline & 27 July & $0.33 \pm 0.27 \mathrm{~b}$ & $0.00 \pm 0.00 \mathrm{a}$ & $0.00 \pm 0.00 \mathrm{a}$ & $0.00 \pm 0.00 \mathrm{a}$ \\
\hline & 5 August & $0.33 \pm 0.27 \mathrm{~b}$ & $0.00 \pm 0.00 \mathrm{a}$ & $0.00 \pm 0.00 \mathrm{a}$ & $0.00 \pm 0.00 \mathrm{a}$ \\
\hline
\end{tabular}

Note. Lowercase letters indicate differences between the treatments within a specific evaluation date.

Table 6. Average number of injuries (holes) caused by wireworms per potato tuber per specific treatment

\begin{tabular}{ccc}
\hline Treatment & Year 2015 & Year 2016 \\
\hline Treatment 1 & $0.04 \pm 0.01 \mathrm{a}$ & $0.5 \pm 0.08 \mathrm{~b}$ \\
Treatment 2 & $0.07 \pm 0.01 \mathrm{~b}$ & $0.35 \pm 0.07 \mathrm{a}$ \\
Treatment 3 & $0.04 \pm 0.01 \mathrm{a}$ & $0.34 \pm 0.07 \mathrm{a}$ \\
Treatment 4 & $0.05 \pm 0.01 \mathrm{ab}$ & $0.56 \pm 0.07 \mathrm{~b}$ \\
\hline
\end{tabular}

Note. Lowercase letters indicate differences between treatments within specific year of experiment.

data collected in 2016 showed the effect of the treatment on the medium $(F=3.17, \mathrm{df}=3, P=0.0366)$ and large $(F=4.12, \mathrm{df}=3, P=0.0255)$ tubers. No treatment effect was detected on the small tubers $(F=0.99$, df $=3$, $P=0.5515)$. The average total yield was also influenced by the treatment $(F=22.15$, df $=3, P<0.0001)$, and the effect was significantly the lowest in treatment $4(25.82 \pm$ $\left.0.27 \mathrm{t} \mathrm{ha}^{-1}\right)$. All the values are presented in Figure 6 .

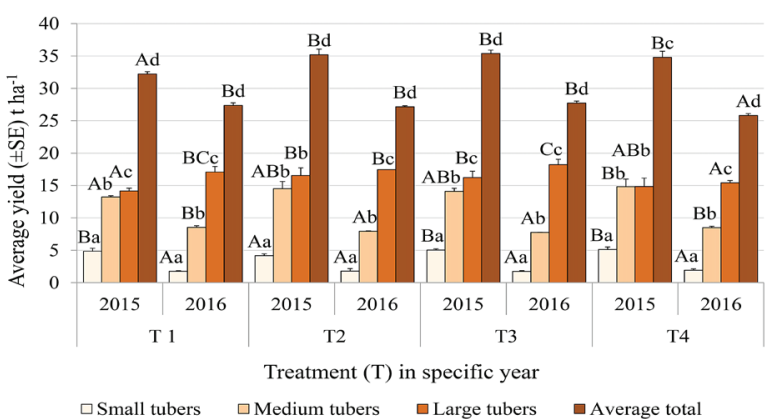

Note. Uppercase letters indicate differences within the same parameter between treatments regarding one year; lowercase letters indicate differences between different parameters within one treatment regarding one year.

Figure 6. The average yield of potato tubers per treatment per size fraction

\section{Discussion}

In our research, we tested the efficacy of three different natural products (limestone dust, calcium cyanamide and Brassica pellets) against insect pests. The efficacy of propolis was tested against two disease agents that cause early and late blight.

The literature reports and agricultural practices (Liška et al., 2017) confirm the efficacy of dust (e.g., diatomaceous earth, zeolites and wood ash) in the suppression of storage pests. Locally accessible dusts are used as insecticides primarily in less developed countries, and wood ash has been successfully used to reduce CPB populations (Boiteau et al., 2012). In a previous study (Tremblay et al., 2005), applications of limestone dust as a soil additive reduced the extent of soil fungi infections. With a low population of the pest in the first year of the experiment, we established the efficiency of limestone dust in reducing the number of CPB during different developmental stages. With the application of limestone dust at a high concentration and a week after the application, we detected no egg clusters or L1-L2 or L3-L4 larvae on the potato plants treated with the dust. The application of limestone dust at the low concentration was only efficient at reducing the number of egg clusters and L1-L2 larvae; however, this reduction occurred only during the application. Limestone dust can be applied preventively (Olle et al., 2015), whereas thiamethoxam is applied when the adults exceed a critical number 0.07 beetles per plant (Mailloux et al., 1995). With the increase in the population of the pest in the second year of the experiment, we applied limestone dust twice. Limestone dust at the high concentration proved to be the most efficient at suppressing the L1-L2 larvae. High concentrations of inert dust are known to suppress storage pests (Bohinc, Trdan, 2017).

Ritter et al. (2014) studied the efficiency of lime nitrogen, which prevents injuries due to wireworms feeding on potatoes, as a repellent, although they did not reach any conclusion regarding its recommended application in practice. However, the results of our research recommend the use of these products, because lime nitrogen displayed the effects that were comparable to those of pyrethroid tefluthrin in the year of a massive infestation by wireworms in 2016. The biofumigation method has been demonstrated to be efficient at reducing injuries by wireworms (Furlan et al., 2010) and other harmful organisms (Main et al., 2014) with different species of cultivated plants. Based on the use of Brassica pellets in our two-year experiment, these pellets cannot be recommended for the control of wireworms, because the potato tubers in the Brassica pellets treatment were as damaged as those in the negative control plots.

Our research included the first study of the fungicidal effects of propolis on potatoes in field conditions. To date, laboratory research has demonstrated the effectiveness of propolis in the reduction in infections by plant pathogens, including Ralstonia solanacearum (Abo-Elyousr et al., 2017), Xanthomonas campestris pv. vesicatoria CECT 792 (Ordónez et al., 2011), Phytophthora infestans, $P$. capsici and $P$. parasitica (Yusuf et al., 2005). When we compared the average 
daily temperatures in the years of our experiment, the average daily temperature in Ljubljana in 2015 was higher than it was in 2016. In both experimental years, the average daily temperature was also higher than the 30-year average temperature (1981-2010). In 2015, the average temperature in the $1^{\text {st }}$ ten days of June was $23.5^{\circ} \mathrm{C}$, and in the $2^{\text {nd }}$ ten days it was $19.8^{\circ} \mathrm{C}$; in the $3^{\text {rd }}$ ten days, the temperature was $18.6^{\circ} \mathrm{C}$. In 2016 , the average temperature in the $1^{\text {st }}$ ten days of June was $18.2^{\circ} \mathrm{C}$, and in the $2^{\text {nd }}$ ten days it was $18.6^{\circ} \mathrm{C}$; in the $3^{\text {rd }}$ ten days, the average daily temperature was $23^{\circ} \mathrm{C}$. The year 2015 was also characterised by a low amount of precipitation. In the $1^{\text {st }}$ ten days of June, Ljubljana received $23.5 \mathrm{~mm}$ of precipitation, and in the $2^{\text {nd }}$ ten days, $19.8 \mathrm{~mm}$ of precipitation was received; in the last ten days, the precipitation was $18.6 \mathrm{~mm}$ (Slovenian Environment Agency, 2018). Therefore, the high average daily temperatures and the low amount of precipitation were the primary reasons why potato blight did not emerge in the first year of the experiment, because the conditions for the spread of the disease were ideal at the time (Becktell, Daughtrey, 2005). The high temperatures in 2015 were also conducive to increasing the efficiency of limestone dust on the CPB, because different dusts are more efficient at high temperatures (Bohinc, Trdan, 2017).

According to Vloutoglu and Kalogerakis (2002), the age of the leaves is an essential factor in the spread of early blight in tomatoes, whereas Olanya et al. (2009) reported the same results for potato. The weather conditions in the years of the experiment also influenced the low level of early blight infection on the potato leaves (less than $10 \%$ in the first year and less than $20 \%$ in the second year of the study in the negative control plots at the end of the growing period), which resulted in the satisfactory efficiency of propolis. According to Olanya et al. (2009), the early blight index of infection increases with increasing temperatures and a sufficient amount of precipitation. Unfavourable conditions for development only cause a delay in the spread of the pathogen, which was the case in our research.

Glosek-Sobieraj et al. (2018) discovered that environmentally acceptable preparations (they applied growth regulators) could successfully influence the health status of a potato crop. Our research confirmed a similar conclusion in the second year, when many of the harmful organisms emerged and we obtained significantly higher tuber yields in all three treatments with preparations than in the untreated plots. When applying environmentally acceptable preparations for the suppression of harmful organisms, preventive application or applying treatment as soon as possible after the emergence of harmful organisms is important (Olle et al., 2015).

\section{Conclusions}

1. Based on the results of the average total potato tuber yield, under low incidences of harmful organisms, the combined use of calcium cyanamide $\left(1000 \mathrm{~kg} \mathrm{ha}^{-1}\right)$, propolis $\left(5 \mathrm{ml} \mathrm{l}^{-1} \mathrm{H}_{2} \mathrm{O}\right)$ and limestone dust $\left(345 \mathrm{~kg} \mathrm{ha}^{-1}\right)$ is suggested; namely the results in this treatment were comparable to those of synthetic chemical pesticides.

2 . In recent years, the number of active ingredients in synthetic fungicides and insecticides has rapidly decreased. As a result, efficient and economic potato tuber production will require their replacement with new, environmentally more acceptable preparations.

\section{Acknowledgements}

The authors are thankful to Jaka Rupnik and Aleš Plut for their technical support. This work was partly performed within P4-0013, which is a programme funded by the Slovenian Research Agency.

\section{References}

1. Abo-Elyousr K. A. M., Seleium M. E. A., ElSharkawy R. M., Khalil Bagy H. M. M. 2017. Effectiveness of Egyptian propolis on control of tomato bacterial wilt caused by Ralstonia solanacearum. Journal of Plant Disease and Protection, 124 (5): 467-472.

https://doi.org/10.1007/s41348-017-0120-x

2. Alyokhin A., Baker M., Mota-Sanchez D., Dively G., Grafius E. 2008. Colorado potato beetle resistance to insecticides. American Journal of Potato Research, 85 (6): 395-413. https://doi.org/10.1007/s12230-008-9052-0

3. Anjum S. I., Ullah A., Khan K. A., Attaullah M., Khan H., Ali H., Bashir M. A., Tahir M., Ansari M. J., Ghramh H. A., Adgaba N., Dash C. N. 2018. Composition and functional properties of propolis (bee glue): a review. Saudi Journal of Biological Sciences. https://doi.org/10.1016/j.sjbs.2018.08.013

4. BBCH Monograph. 2001. Growth stages of mono- and dicotyledonous plants. Meier U. (ed.). Federal Biological Research Centre for Agriculture and Forestry. https://www. politicheagricole.it/flex/AppData/WebLive/Agrometeo/ MIEPFY800/BBCHengl2001.pdf

5. Becktell M. C., Daughtrey M. L. 2005. Temperature and leaf wetness requirements for pathogens establishment, incubation period, and sporulation of Phytophthora infestans on Petunia $\times$ hybrida. Plant Disease, 89 (9): 975-979. https://doi.org/10.1094/PD-89-0975

6. Bohinc T., Trdan S. 2014. Alternative methods for controlling wireworms (Coleoptera, Elateriadea) in the fields. Acta Agriculturae Slovenica, 101 (1): 167-177 (in Slovenian)

7. Bohinc T., Trdan S. 2017. Comparison of insecticidal efficacy of four natural substances against granary weevil (Sitophilus granaries L.) adults: does the combined use of the substances improve their efficacy? Spanish Journal of Agricultural Research, 15 (3): e1009. https://doi.org/10.5424/sjar/2017153-11172

8. Bohinc T. Znidarčič D. Trdan S. 2015. Comparison of field efficacy of four natural fungicides and metiram against late blight (Phytophthora infestans [Mont] de Bary) on tomato short communication. Horticultural Science, 42 (4): 215-218. https://doi.org/10.17221/366/2014-HORTSCI

9. Boiteau G. S., McCarthy R. P., MayKinley P. D. 2012. Wood ash potential for Colorado potato beetle control. American Journal of Potato Research, 89 (2): 129-135. https://doi.org/10.1007/s12230-012-9234-7

10. Christ B. J., Haynes K. G. 2001. Inheritance of resistance to early blight disease in a diploid potato production. Plant Breeding, 120 (2): 169-172. https://doi.org/10.1046/j.1439-0523.2001.00565.x

11. Furlan L., Bonetto C., Finotto A., Lazzeri L., Malaguti L., Patalano G., Parker W. 2010. The efficacy of biofumigant meals and plants to control wireworms populations. Industrial Crops and Products, 31 (2): 245-254. https://doi.org/10.1016/j.indcrop.2009.10.012

12. Glosek-Sobieraj M., Cwalina-Ambroziak B., Hamouz K. 2018. The effect of growth regulators and a biostimulator on the health status, yield and yield components of potatoes (Solanum tuberosum L.). Gesunde Pflanzen, 70 (1): 1-11. https://doi.org/10.1007/s10343-017-0407-7

13. Kapsa J. Z. 2008. Important threats in potato production and integrated pathogen / pest management. Potato Research, 51:385-401. https://doi.org/10.1007/s11540-008-9114-1

14. Laznik Ž., Tóth T., Lakatos T., Vidrih M., Trdan S. 2010. Control of the Colorado potato beetle (Leptinotarsa decemlineata [Say]) on potato under field conditions: a comparison of the efficacy of foliar application of two strains of Steinernema feltiae (Filipjev) and spraying with thiametoxam. Journal of Plant Diseases and Protection, 117 (3): 129-135. https://doi.org/10.1007/BF03356348

15. Laznik Ž., Trdan S., Vučajnk F., Bohinc T., Vidrih M. 2014 Cruciferous plants' use as biofumigants in potato against wireworms. Acta Agriculturae Scandinavica, Section B: Soil and Plant Science, 64 (7): 606-614. https://doi.org/10.1080/09064710.2014.941391

16. Liška A., Korunić Z., Rozman V., Halamič J., Galovivić I., Lucić, P., Baličević, R. 2017. Efficacy of nine Croatian inert dusts against rice weevil Sitophilus oryzae L. (Coleoptera: Curculionidae) on wheat. Emirates Journal of Food and Agriculture, 29 (7): 485-494. https://doi.org/10.9755/ejfa.2016-09-1302

17. Mailloux G., Bostanian N. J., Binns M. R. 1995. Density yield relationship for Colorado potato beetle adults on potato. Phytoparasitica, 23 (2): 101-118. https://doi.org/10.1007/BF02980970

18. Main M., McCafferey J. P., Morra M. J. 2014. Insecticidal activity of Brassica juncea seed meal to the fungus gnat Bradysia impaties Johannsen (Diptera: Sciaridae). Journal of Applied Entomology, 138 (9): 701-707. https://doi.org/10.1111/jen.12128 
19. Nærstad R., Hermansen A., Bjor T. 2007. Exploiting host resistance to reduce the use of fungicides to control potato late blight. Plant Pathology, 56 (1): 156-166. https://doi.org/10.1111/j.1365-3059.2006.01491.x

20. OEPP/EPPO. 1997. EPPO Standards. Guidelines for the efficacy evaluation of plant protection products. Fungicides and Bactericides, 2: 4-7.

21. Olanya O. M., Honeycutt C. W., Larkin R. P., Griffin T. S., He Z., Halloran J. M. 2009. The effect of cropping systems and irrigation management on development of potato early blight. Journal of Genetics and Plant Pathology, 75 (4): 267-275. https://doi.org/10.1007/s10327-009-0175-z

22. Olle M., Tsahkna A., Tahtjarv T., Williams I. H. 2015 Plant protection for organically grown potatoes - a review. Biological Agriculture and Horticulture, 31 (3): 147-157. https://doi.org/10.1080/01448765.2014.983546

23. Ordónez R. M., Zampini I. C., Nieva Moreno M. I., Isla M. I. 2011. Potential application of Northern Argentine propolis to control some phytopathogenic bacteria. Microbial Research, 166 (7): 578-584. https://doi.org/10.1016/j.micres.2010.11.006

24. Pulatov B., Jönsson A. M., Wilcke R. A. I., Linderson M. L., Hall K., Bärring L. 2016. Evaluation of the phenological synchrony between potato crop and Colorado potato beetle under future climate in Europe. Agriculture, Ecosystems and Environment, 224 (15): 39-49. https://doi.org/10.1016/j.agee.2016.03.027

25. Rinkevich F. D., Su C., Lazo T. A., Hawthorne D. J., Tingey W. M., Naimov S., Scott J. G. 2012. Multiple evolutionary origins of knockdown resistance $(\mathrm{kdr})$ in pyrethroidresistant Colorado potato beetle, Leptinotarsa decemlineata. Pesticide, Biochemistry and Physiology, 104 (3): 192-200. https://doi.org/10.1016/j.pestbp.2012.08.001

26. Ritter C., Richter E. 2013. Control methods and monitoring of Agriotes wireworms (Coleoptera: Elateridae). Journal of Plant Diseases and Protection, $120(1): 4-15$. https://doi.org/10.1007/BF03356448

27. Ritter C., Richter E., Knölck I, Katroschan K. U. 2014. Laboratory studies on the effect of calcium cyanamide on wireworms (Agriotes ustulatus, Coleoptera: Elateridae). Journal of Plant Diseases and Protection, 121 (3): 133-137. https://doi.org/10.1007/BF03356501
28. Rogge S. A., Mayerhofer J., Enkerli J., Bacher S., Grabenweger G. 2017. Preventive application of an entomopathogenic fungus in cover crops for wireworm control. Biocontrol, 62 (5): 613-623. https://doi.org/10.1007/s10526-017-9816-x

29. Runno-Paurson E., Hansen M., Tein B., Loit K., Jogi K, Luik A., Metspalu L., Eremeev V., Williams I. H., Mand M. 2014. Cultivation technology influences the occurrence of potato early blight (Alternaria solani) in an organic farming system. Zemdirbyste-Agriculture, 101 (2): 199-204.

https://doi.org/10.13080/z-a.2014.101.026

30. Scott I. M., Tolman J. H., MacArthur D. C. 2014. Insecticide resistance and cross-resistance development in Colorado potato beetle Leptinotarsa decemlineata Say (Coleopetra: Chrysomelide) populations in Canada 2008-2011. Pest Management Science, 71 (5): 712-721. https://doi.org/10.1002/ps.3833

31. Slovenian EnvironmentAgency. 2018. http://www.arso gov. si/o\%20agenciji/knji\%C 5\%BEnica/mese $\%$ C4\%8Dni\%20 bilten/ (in Slovenian)

32. Sufyan M., Neuhoff D., Furlan L. 2013. Effect of male mass trapping of Agriotes species on wireworm abundance and potato tuber damage. Bulletin of Insectology, 66 (1): 135-142.

33. Tremblay N., Belec C., Coulombe J., Godin C. 2005. Evaluation of calcium cyanamide and liming for control of clubroot disease in cauliflower. Crop Protection, 24 (9): 798-803. https://doi.org/10.1016/j.cropro.2004.12.013

34. Vloutoglu I., Kalogerakis S. N. 2000. Effects of inoculum concentration, wetness duration and plant age on development of early blight (Alternaria solani) and on shedding of leaves in tomato plants. Plant Pathology, 49 (3): 339-345. https://doi.org/10.1046/j.1365-3059.2000.00462.x

35. Wang C., Hawthorne D., Qin Y. J., Pan X. B., Li Z. H., Zhu S. F. 2017. Impact of climate and host availability on future distribution of Colorado potato beetle. Scientific Reports, 7: 4489. https://doi.org/10.1038/s41598-017-04607-7

36. Yusuf Y., Durdane Y., Servet A. 2005. Antifungal activity of Turkish propolis against Phytophthora species. Plant Pathology Journal, 4 (1): 58-60. https://doi.org/10.3923/ppj.2005.58.60

ISSN 1392-3196 / e-ISSN 2335-8947

Zemdirbyste-Agriculture, vol. 106, No. 2 (2019), p. 135-142

DOI 10.13080/z-a.2019.106.018

\title{
Alternatyvių augalų apsaugos produktų efektyvumas nuo pagrindinių bulvių kenkèjų ir ligų
}

\author{
T. Bohinc, F. Vučajnk, S. Trdan \\ Liublianos universitetas, Slovėnija
}

\section{Santrauka}

Aplinkai nekenksmingi produktai, skirti žalingu organizmu - Kolorado vabalu (Leptinotarsa decemlineata), spragšiu (Agriotes spp.), sausligès (Alternaria solani) ir maro (Phytophthora infestans) - kontrolei bulviu pasèliuose buvo tirti 2015-2016 m. Kolorado vabalu kontrolei tirtas dvieju 345 ir $690 \mathrm{~kg} \mathrm{ha}^{-1}$ normu kalkakmenio miltelių efektyvumas. Spragšių kontrolei naudota bastutinių (Brassica) augalų šeimos augalų granulès $\left(200 \mathrm{~g} \mathrm{~m}^{-2}\right)$ ir kalcio cianamidas $\left(1000 \mathrm{~kg} \mathrm{ha}^{-1}\right)$. Nuo bulviu sausligès ir maro tirta 5 ir $10 \mathrm{ml} \mathrm{1}^{-1} \mathrm{H}_{2} \mathrm{O}$ propolio ir propolio glikolio ekstrakto tinktūros (pavadintos propoliu). Tirti keturi alternatyvių augalų apsaugos produktų variantai. Pirmajame variante naudoti kalkakmenio milteliai $\left(690 \mathrm{~kg} \mathrm{ha}^{-1}\right)$, Brassica granulès ir bičiu pikis $\left(10 \mathrm{ml}^{-1} \mathrm{H}_{2} \mathrm{O}\right)$. Antrajame variante naudoti kalkakmenio milteliai $\left(345 \mathrm{~kg} \mathrm{ha}^{-1}\right)$, kalcio cianamidas $\left(1000 \mathrm{~kg} \mathrm{ha}^{-1}\right)$ ir bičiu pikis $\left(5 \mathrm{ml} \mathrm{l}^{-1} \mathrm{H}_{2} \mathrm{O}\right)$. Trečiasis variantas buvo teigiamas kontrolinis - taikytas registruotu fitofarmaciniu augalu apsaugos produktų metodas, ketvirtasis - neigiamas kontrolinis - augalai nebuvo apdoroti. Vertinti visi Kolorado vabalų vystymosi tarpsniai: kiaušinèliai, pirmos ir antros stadijos lervos po išsiritimo (L1-L2), trečios ir ketvirtos stadijos lervos po išsiritimo (L3-L4, suaugèliai). Po derliaus nuėmimo nustatytas mažu, vidutinio dydžio ir didelių bulvių gumbų derlius. Taip pat nustatyti ant įvairaus dydžio bulvių gumbų spragšių padaryti pažeidimai. Tyrimo duomenys parodè, kad nuo spragšiu kalcio cianamidas buvo efektyvesnis už Brassica granules. Bičiu pikio $10 \mathrm{ml} \mathrm{1}^{-1} \mathrm{H}_{2} \mathrm{O}$ norma buvo efektyvi alternatyvi priemonè kontroliuojant sausligę ir marą ligos epideminiam protrūkiui nepalankiomis salygomis. $2016 \mathrm{~m}$. bulviu gumbu derlius, panaudojus tirtus augalu apsaugos produktus, buvo esmingai didesnis nei laukeliuose, kuriuose šie produktai nebuvo naudoti.

Kuriant ateities bulviu auginimo sistemas, derinant tirtus produktus galima formuoti alternatyvias kenkèju naikinimo strategijas. Jos bus tinkamos ūkininkaujant kintančio klimato sąlygomis, o tirti produktai papildys dar labai siaurą registruotų fitofarmakologinių augalų apsaugos produktų asortimentą.

Reikšminiai žodžiai: Brassica granulès, bulvės, derlius, kalcio cianamidas, kalkakmenio milteliai, kenkèjai, ligos, pikis. 